\title{
Implementation of discovery learning on electromagnetic wave material based on adsorption Congo Red by silica from Bengkulu beach sand
}

\author{
M. Lutfi Firdaus *, Sasti Yuliafitri, Eko Swistoro, Ghufira, Rendy W. Wardana \\ Pascasarjana Pendidikan IPA, Universitas Bengkulu. Jalan WR Supratman, Bengkulu 38371, Indonesia. \\ * Corresponding Author. Email: lutfi@unib.ac.id
}

\begin{tabular}{|c|c|}
\hline & ABSTRACT \\
\hline $\begin{array}{l}\text { Keywords: } \\
\text { Discovery learning; } \\
\text { Critical thinking } \\
\text { skill; } \\
\text { Electromagnetic } \\
\text { wave; Learning } \\
\text { model. }\end{array}$ & $\begin{array}{l}\text { This study aims to describe the differences in students' critical thinking skill between class } \\
\text { which use discovery learning and conventional learning in electromagnetic wave material. The } \\
\text { research method used was a quasi-experimental method with a non-equivalent control group } \\
\text { design which was conducted in MAS } 01 \text { Darussalam Kepahiang. In non-equivalent control } \\
\text { group design, the sample (was) not taken randomly but by purposive sampling technique. The } \\
\text { research sample taken by the researcher consists of two classes, (i.e.) the class XII A2 as an } \\
\text { experimental class and the class XII A3 as a control class. Both classes were given a pretest to } \\
\text { find out the students' fundamental critical thinking skills and a posttest to find out the students' } \\
\text { final critical thinking skills. This research was conducted in two meetings according to } \\
\text { subchapters on electromagnetic wave material. Discovery learning model was applied in the } \\
\text { experimental class with the steps of learning are stimulation, prob09lem statement, data } \\
\text { collection, data processing, verification, and generalization. The average value of critical } \\
\text { thinking of the experimental class student was } 65.7 \text { and (the) control class was } 48.12 \text { with a } \\
\text { value of sig. ( } 2 \text {-tailed) }=0.000<\text { sig. } \alpha=0.05 \text {. Based on the results, it can be concluded that } \\
\text { there is a significant difference in students' ' critical thinking skills using the discovery learning } \\
\text { model with the critical thinking skills of students using conventional learning. }\end{array}$ \\
\hline
\end{tabular}

C2019 JSER. Yogyakarta State University

\section{INTRODUCTION}

Teaching is a learning process built by teachers to develop students 'thinking skills that can improve students' ability to construct new knowledge; learning is also an effort to improve good mastery of subject matter (Abidin, 2014). The thinking skill is needed as a means to achieve educational goals so that students are able to solve high-level problems (Departemen Pendidikan Nasional, 2008).

Physics is a branch of science studying natural phenomena that occur in life. Physics requires more understanding because it contains knowledge in the form of facts, laws, concepts, principles and theories about natural phenomena. To understand these natural phenomena, students' analytical thinking skills are needed and it can be developed by training students to understand physical concepts directly (Asmawati, 2015). It requires the teacher and students to be actively involved in the learning process.

Based on the results of preliminary observations and interviews with physics teachers at MAS 01 Darussalam Kepahiang, it is known that students still experience difficulties in interpreting physics concepts. Students also have low ability to think. Students are not familiar with analyzing problems, solving problems, and making decisions. The teacher also still uses conventional learning which is dominated by teachers so that the learning process is centered on the teacher, students only listen and take notes and then occasional questions and answers. Thus, one of the factors that influences the low ability of students to think critically is a learning model that lack of critical thinking skills.

The step to improve students' thinking skills is through the selection of appropriate learning models and require students to solve problems related to physical concepts through critical thinking, so that teaching learning process becomes more active, meaningful and enjoyable. There are several learning models that can develop students' critical thinking skills, one of which is by applying the discovery learning model.

Discovery learning model is a learning model to develop active student learning by discovering on their own, investigating on their own, then the results obtained will last long in memory or will not be easily forgotten by students. Through discovery learning, students can also learn to think analytically 
M. Lutfi Firdaus, Sasti Yuliafitri, Eko Swistoro, Ghufira, Rendy W. Wardana / JSER 2019, 3(2), 104

and try to solve their own problems. These habits will be transferred in social life (Hosnan, 2014). Discovery learning model provides opportunities for students to think, discover, argue, and cooperate with each other through scientific learning activities so as to practice critical thinking skills, problem solving, and obtain important concepts that will later have an impact on improving learning outcomes (Sapitri et al, 2016). Discovery learning model can be applied to a variety of physics subject matter, one of which is on the learning of electromagnetic wave material.

Spectrophotometer using the spectroscopy method is one of the applications of electromagnetic waves. The function of the spectrophotometer is to measure the absorbance of a sample with light at a specific wavelength. Each medium will absorb light at a specific wavelength depending on the compound formed or color (Cairns, 2012). One of the samples that can be used is silica from the Panjang Beach quartz sand as one of the natural resources in Bengkulu Province. In this research, measurement of textile dye adsorption, namely Congo Red by Panjang sand silica with spectroscopic methods. The use of electromagnetic waves in technology can be developed as a student worksheet (L KS) that can be used in classroom learning activities. The use of worksheets as learning aids will make students more active because they are in accordance with the chosen learning model (Suryani et al, 2016).

Based on the description above, the purpose of this study is to describe the differences of students' critical thinking skills between class which implement discovery learning model assisted by worksheets with class which implement conventional model.

\section{METHOD}

This research was conducted from 10 July 2019 to 31 July 2019 in MAS 01 Darussalam Kepahiang in the 2019/2020 school year. The method in this study is a quasi-experimental method with the research design used in nonequivalent control group design. The study design is shown in Table 1.

Tabel 1. Nonequivalent Control Group Design

\begin{tabular}{lrcc}
\hline Class & Pretest & Treatment & Postest \\
\hline Experiment & $\mathrm{O}_{1}$ & $\mathrm{X}$ & $\mathrm{O}_{2}$ \\
Control & $\mathrm{O}_{3}$ & $\mathrm{Y}$ & $\mathrm{O}_{4}$ \\
\hline
\end{tabular}

The population was all students of class XII IPA MAS 01 Darussalam Kepahiang, amounting to 3 classes in odd semester 2019/2020 academic year. The sample in the study was selected by purposive sampling technique. The sample in this study are two classes, namely class XII A2 with 25 people and XII A3 with 24 people. The experimental class was given treatment in the form of discovery learning model while the control class was given conventional learning model.

The steps of the discovery learning model undertaken include the stimulation phase, namely providing motivation to focus on the topic and asking questions, suggesting reading and other activities to lead to preparation of problem solving; the problem statement stage is to identify as many problems as possible related to the subject matter which are then formulated in the form of a hypothesis; the data collection stage, namely gathering relevant information to answer questions through literature studies, experiments or observations; data processing stage, namely processing the data of observations by discussion of the results of observations and paying attention to questions on the activity sheet; verification phase which is verifying the results of data processing with data at the source and doing a careful examination to prove the hypothesis; and the generalization stage, that is drawing conclusions.

Data collection techniques used critical thinking skills test items in the form of essays as many as 5 questions with electromagnetic wave material that contains indicators of critical thinking ability that will be measured: the ability to focus questions, consider the credibility of a source, analyze arguments, identify assumptions, make inductions and consider induction results. Students' critical thinking skills is measured using the following formula:

$$
x=\frac{\text { Achieved Score }}{\text { Max Score }} x 100
$$

Criteria for the ability to think critically according to Purwanto and Nughoro (2012) with the following indicators:

$$
\begin{array}{ll}
81,25<\mathrm{x} \leq 100 & : \text { very critical } \\
62,51<\mathrm{x} \leq 81,25 & : \text { critical } \\
43,76<\mathrm{x} \leq 62,50 & : \text { quite critical } \\
25,00<\mathrm{x} \leq 43,75 & : \text { less critical }
\end{array}
$$

To answer the hypothesis, it is done through inferential analysis by means of a data normality test, a variance homogeneity test, and a two-similarity test. If both the data are normal and homogeneous, then the statistical test used is the t-test (Sudjana, 1996).

\section{RESULT AND DISCUSSION}

\section{Early Students' Critical Thinking Skills}

Pretest was conducted to determine the students' initial ability to electromagnetic wave material. Pretest is done twice at the beginning of the learning meeting. Based on the calculation results, a summary of the results of the pretest can be seen in Table 2 . 
M. Lutfi Firdaus, Sasti Yuliafitri, Eko Swistoro, Ghufira, Rendy W. Wardana / JSER 2019, 3(2), 105

Tabel 2. Recapitulation of Pretest Results Data

\begin{tabular}{llc}
\hline \multicolumn{1}{c}{ Category } & $\begin{array}{c}\text { Experiment } \\
\text { class }\end{array}$ & $\begin{array}{c}\text { Control } \\
\text { class }\end{array}$ \\
\hline 1. Average value & 13,7 & 12,60 \\
2. Standard Deviation & 6,12 & 6,89 \\
3. The highest score & 27,50 & 27,50 \\
4. The lowest score & 5,00 & 2,50 \\
\hline
\end{tabular}

Based on table 2 it can be seen that the average value of the experimental class pretest is 13.7 and the control class is 12.60 . The pretest data above shows descriptively critical thinking skills between the experimental class and the control class. There is no such a big difference because electromagnetic wave material has not been studied by students. The category of critical thinking skills for both classes is less critical.

\section{Students' Final Critical Thinking Skills}

Post-test was conducted to determine the students' final critical thinking abilities on electromagnetic wave material after receiving different learning treatments. This test was conducted to determine differences in students' critical thinking skills after receiving a physics learning treatment by using the discovery learning model in the experimental class and by using conventional learning in the control class. Based the calculation results, the recapitulation of the post-test results can be seen in Table 3.

Table 3. Recapitulation of Post Test Results Data

\begin{tabular}{clcc}
\hline No. & \multicolumn{1}{c}{ Category } & $\begin{array}{c}\text { Experiment } \\
\text { class }\end{array}$ & Control class \\
\hline 1. & Average value & 65,70 & 48,12 \\
2. & Standard deviation & 9,61 & 13,17 \\
3. & The highest score & 80,00 & 70,00 \\
4. & The lowest score & 47,50 & 25,00 \\
\hline
\end{tabular}

Based on Table 3 it can be seen that the average post test score of the experimental class is 65.70 and in the control class is 48.12. The data above shows descriptively the results of tests of students' critical thinking skills between the experimental class and the control class. For a clearer difference in the average value of the post-test experimental class and the control class can be seen graphically in Figure 1.

Based on the graph in Figure 1, it is known that the posttest value for the experimental class using the discovery learning model is different from the posttest value of the control class that uses conventional learning. The average value of the posttest at first and second meeting of the control class showed that the category of critical thinking skills of students was in the quite critical category, while the average value of the posttest at first and second meeting of the experimental class showed the category of students' critical thinking skills in the critical category.

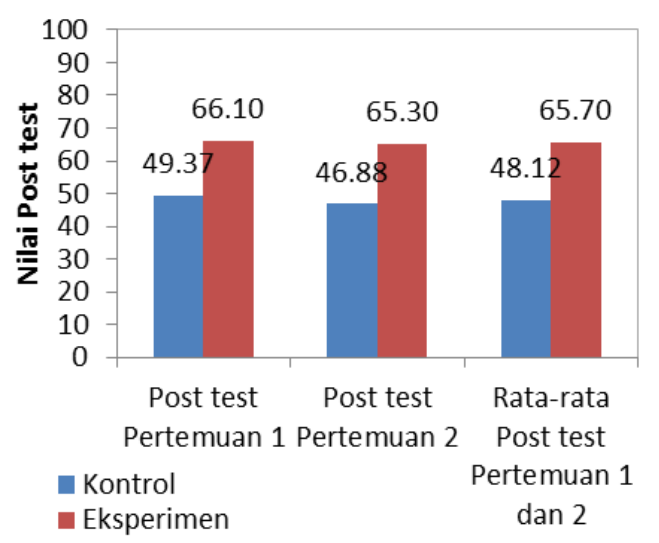

Figure 1. Graph of pretest and posttest mean scores of the experimental class and the control class

Students' critical thinking skills through discovery learning model can be trained and developed. This can be proven by comparing the average value of each indicator of students' critical thinking skills in the control class and the experimental class. Indicators of critical thinking skills developed include the following: (1) focusing questions; (2) considering the credibility of a source; (3) analyzing arguments; (4) identifying assumptions; (5) making induction and considering the results of induction. The difference in the average value of each indicator at meeting 1 can be seen graphically in Figure 2.

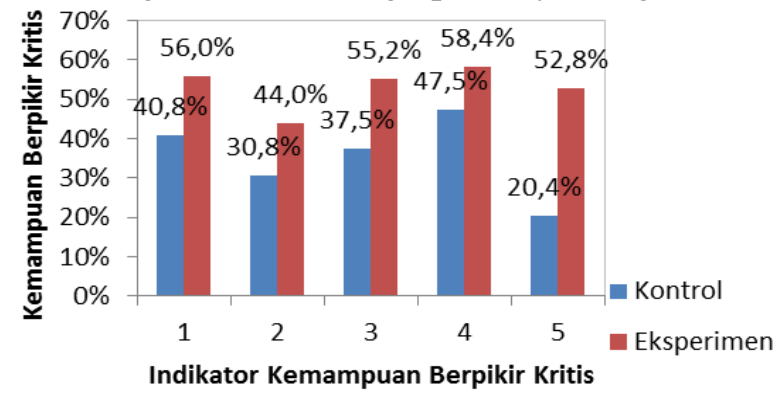

Figure 2. Percentage Graph Average Value of Each Indicator of Students' Critical Thinking Ability at First Meeting

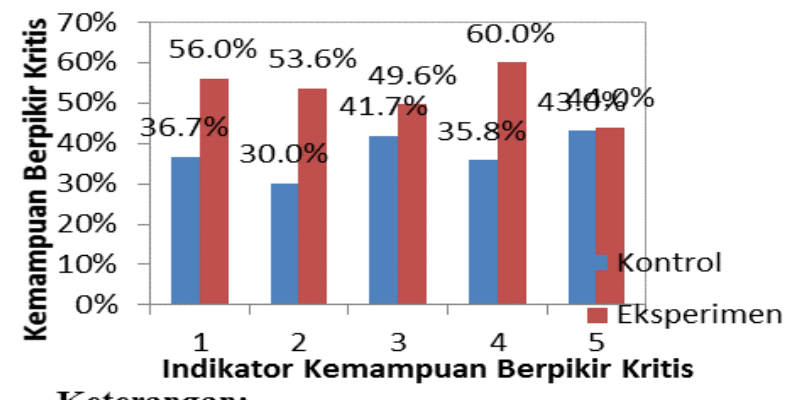

Keterangan:

1. memfokuskan pertanyaan

2. mempertimbangkan kredibelitas suatu sumber

3. menganalisis argumen

4. mengidentifikasi asumsi-asumsi

Figure 3. Percentage Graph Average Value of Every Indicator of Students' Critical Thinking Skills in Second Meeting 
M. Lutfi Firdaus, Sasti Yuliafitri, Eko Swistoro, Ghufira, Rendy W. Wardana / JSER 2019, 3(2), 106

The difference in the average value of each indicator at second meeting can be seen graphically in Figure 3. Based on Figure 2 and Figure 3, it is known that there is always a difference in the percentage of the average value of each indicator of the experi-mental class and the control class. At meeting 1 there was a significant difference in indicator 5 , namely the ability to make induction and consider the results of induction. The difference in the average value is because in the experimental class students are trained to conclude the results of the experiment and discussion and verification which are used as general principles and apply to all events or problems by paying attention to verification (generalization stage). At second meeting, there was a significant difference in indicator 4 (identifying assumptions). This difference is because students in the experimental class are trained to process observational data by discussing observations by paying attention to the questions on the activity sheet (data processing stage).

Thus, based on the description above, it can be seen that learning using discovery learning models can improve students' critical thinking skills. This is supported by Nugrahaeni et al (2017) stating differences in students' critical thinking skills due to the learning process using the discovery learning model trains students to find their own answers to the problems given by studying, analyzing, verifying, formulating and making conclusions and each indicator of ability critical thinking has been fullfilled in learning activities in line with the syntax contained in the discovery learning model used.

\section{Hypothesis testing}

From the results of normality and homogeneity test data on the average pretest of first and second meeting, it can be concluded that both classes are normally distributed and homogeneous, then the parametric $t$ test using SPSS is conducted. Test criteria if the significant value (sig) $>\alpha(0.05)$ then $\mathrm{H} 0$ is accepted, if the significant value (sign) $<\alpha(0.05)$ then $\mathrm{H} 0$ is rejected. In the $t$ test calculation using the SPSS 25 application and the hypothesis used:

Ho $=$ There is no difference between the mean score of the experimental class and the mean score of the control class.

$\mathrm{Ha}=$ There is a difference between the average score of the experimental class and the average score of the control class.

Based on the results of the calculation of the pretest and posttest test of the experimental and control classes can be seen in Table 4 .
Table 4. Pretest and Posttest Test Results

\begin{tabular}{cccl}
\hline Tes & sig. $\alpha$ & $\begin{array}{c}\text { Sig } \\
\text { (2-Tailed) }\end{array}$ & \multicolumn{1}{c}{ Conclusion } \\
\hline Pretest & 0,05 & 0,559 & Not significantly different \\
Posttest & 0,05 & 0,000 & Significantly different \\
\hline
\end{tabular}

From the table of t test results, it is known that for the pretest value obtained sig. (2-tailed) $=$ 0.559 greater than $\alpha=0.05$ thus it can be stated that there is no significant difference in the initial critical thinking abilities of experimental class students and class students control, while the posttest sig. (2tailed) $=0,000$ is smaller than $\alpha=0.05$. Thus the Ho hypothesis is rejected, it can be concluded that there are differences in the average critical thinking ability of students using the discovery learning model with the average critical thinking ability of students who use conventional learning.

\section{CONCLUSION}

Based on the results of research and discussion previously described, it can be concluded that there is a significant difference between students 'critical thinking abilities using discovery learning models with students' critical thinking skills using conventional learning. The average value of the final critical thinking ability of the experimental class students showed a value of 65.7 (critical category) and a control class of 48.12 (quite critical category) with a value of sig. (2-tailed) $=$ $0,000<$ sig. $\alpha=0.05$.

Discovery learning model can be applied to a variety of physics learning materials so that it can be used as one of the references for subsequent research, in conducting research so that more attention is given to research instruments and more emphasis is applied to the steps of discovery learning so that its contribution to students' critical thinking skills can be seen.

\section{REFERENCES}

Abidin, Y. (2014). Desain sistem pembelajaran dalam konteks kurikulum 2013. Refika Aditama.

Asmawati, E. Y. (2015). Lembar kerja siswa (LKS) menggunakan model guided inquiry untuk meningkatkan keterampilan berpikir kritis dan penguasaan konsep siswa. Jurnal Pendidikan Fisika, 3(1).

Cairns, D. (Ed.). (2012). Essentials of pharmaceutical chemistry. Pharmaceutical Press.

Departemen Pendidikan Nasional. (2008). Berbagai pendekatan dalam proses belajar mengajar. Jakarta: Depdiknas.

Hosnan, M. (2014). Pendekatan saintifik dan kontekstual dalam pembelajaran abad 21: 
M. Lutfi Firdaus, Sasti Yuliafitri, Eko Swistoro, Ghufira, Rendy W. Wardana / JSER 2019, 3(2), 107

Kunci sukses implementasi kurikulum 2013. Ghalia Indonesia.

Nugrahaeni, A., Redhana, I. W., \& Kartawan, I. M. A. (2017). Penerapan model pembelajaran discovery learning untuk meningkatkan kemampuan berpikir kritis dan hasil belajar kimia. Jurnal Pendidikan Kimia Indonesia, l(1), 23-29.

Purwanto, C. E., \& Nughoro, S. E. (2012). Penerapan model pembelajaran guided discovery pada materi pemantulan cahaya untuk meningkatkan berpikir kritis. UPEJ Unnes Physics Education Journal, 1(1).
Sapitri, U. E., Kurniawan, Y., \& Sulistri, E. (2016). Penerapan Model Discovery Learning Untuk Meningkatkan Keterampilan Berpikir Kritis Siswa Kelas X Pada Materi Kalor. JIPF (Jurnal Ilmu Pendidikan Fisika), 1(2), 64-66.

Sudjana, N. (2005). Metode statistika. Bandung: Tarsito

Suryani, I., Mardiati, Y., \& Herlanti, Y. (2016). Pengaruh Penggunaan Lembar Kerja Siswa (LKS) Berbasis Kontekstual Terhadap Hasil Belajar Siswa Pada Konsep Sistem Gerak Manusia. EDUSAINS, 8(2), 150-156. 